\title{
Gendered Ambition and Disappointment: Women and Men in a Vernacular Language Education Movement in Melanesia
}

\author{
Debra McDougall
}

\section{Introduction}

'They ruin us when they teach English first'

$$
\begin{array}{r}
\text {-18-year-old man of Ranongga Island, } \\
\text { Solomon Islands }
\end{array}
$$

Young people of Solomon Islands are expected to learn to read and write in English, a language that many do not speak or understand well. Most rural children grow up speaking one (sometimes several) of the country's more than 70 indigenous languages as well as the neo-Melanesian English-based creole Pijin; some urban children learn the indigenous language of their rural-born parents or grandparents, but most grow up speaking Pijin, which is the language of urban life (Jourdan, 2013). Multilingualism, rather than monolingualism, is the norm rather than the exception in Solomon Islands; people move fluidly between different indigenous languages, Pijin and English. Yet few feel entirely confident in English - the country's official language, the language of status and the language of schooling. Even tertiary-trained teachers often lack confidence 
in their mastery of English and use Pijin as the language of instruction (Tanangada, 2013). English-only education is particularly devastating for rural children, who are already disadvantaged in the Solomon Islands educational system.

For decades, scholars of multilingual education and language policy have argued that children learn best when taught in their first language (Ball, 2011; Lo Bianco, 2015; United Nations Educational, Scientific and Cultural Organization, 1953). Resistance to first-language education policies is often based on the false assumption that the sooner children learn a standardised national or global language, the more likely they are to master it. In fact, longer and more intensive study of a first language almost always leads to better levels of literacy in the national or global standard. Ten years ago, the Solomon Islands Ministry of Education and Human Resource Development (MEHRD) adopted a policy that embraces the right of children to be taught in vernacular languages for these sound pedagogical reasons and to affirm cultural diversity in the country (Jourdan, 2013; MEHRD, 2010). Unfortunately, the policy has not been implemented beyond two pilot projects. ${ }^{1}$

Outside the formal system, however, some individuals and communities have established schools that promote the use of vernacular language. Gegeo and Watson-Gegeo (2012), for example, describe an initiative among Kwara'ae people of North Malaita that began in the years following the 1998-2003 ethnic crisis. This crisis caused both a nation-wide disruption to schooling and a massive influx of Honiara residents whose parents or grandparents came from Kwaraae, but who lacked linguistic and cultural knowledge that is essential to rural life. Such initiatives form part of the highly localised autonomy movements discussed in the Introduction (Bainton \& McDougall, this volume)—instances in which remarkable leaders mobilise communities to do for themselves what colonial or postcolonial governments have failed to do.

\footnotetext{
1 Advocates of multilingual education in Solomon Islands are frustrated by the slow rollout of the policy; however, the fate of a similar policy in nearby Papua New Guinea (PNG) illustrates the negative consequences of hasty implementation. In PNG, transitional bilingual education was established in the late 1990s without sufficient teacher training or curriculum materials. Many parents and teachers blamed vernacular language education, in addition to other reforms including outcomes-based education, for poor educational outcomes. By the end of 2012, then prime minister Peter O'Neill led a return to a system that used English as both medium of instruction and subject of study from early primary school (Devette-Chee, 2015; Litteral, 2015; Merlan \& Rumsey, 2015; Troolin, 2013).
} 
My focus in this chapter is the Kulu Language Institute of Ranongga Island, a remarkable language movement that has allowed thousands of youth and adults to study their own language. I draw on material from more than 50 interviews conducted with people involved with the Kulu Institute in November 2017, follow-up work in September 2019 and two decades of study of Ranonggan social life and history (McDougall, 2016). Kulu comes from the names of two languages spoken on the Western Province island of Ranongga: Kubokota and Luqa. The work of the Kulu Language Institute began in 1998 as a modest attempt to teach villagers to read a Luqa language translation of the New Testament. Over two decades, it has grown to become a powerful force in the intellectual life of Ranongga. Hundreds of students each year pay modest fees for intensive courses (over one or two weeks) in language study. The curriculum is a sophisticated monolingual description of the structure of the language, authored by Dr Alpheaus Graham Zobule, a Luqa man with multiple tertiary degrees, including a $\mathrm{PhD}$ in theology. Like the middle-class Papua New Guineans described in this volume by John Cox, and an earlier generation of tertiary-educated men of the Western Pacific who led 'thought rebellions' in the era of global decolonisation (Banivanua-Mar, 2016, pp. 195-204), Zobule is committed to using his formidable intellect and training to help people of his home island. While other vernacular language programs in the country focus on basic literacy, students at the Kulu Institute move far beyond literacy to explore the underlying structures and expressive possibility of Luqa language (McDougall \& Zobule, forthcoming).

The young man quoted in the epigraph grew up on his father's land, speaking Luqa as his first language. Like most speakers of Luqa, he understands Kubokota. He also speaks a language of Choiseul Province (his mother's first language), Solomon Islands Pijin and English, which he studied for 12 years in school. On the face of it, he seemed to be an education success story; he had passed the competitive examinations that push a majority of students out of upper secondary education. And yet he told me about how ashamed he always felt in school when he was called upon to stand in front of the class and read aloud. After taking the first intensive course in Luqa language in his home village, he decided to withdraw from his final year of secondary school to complete the sequence of courses on Luqa grammar. In the Kulu classrooms, he learned to enjoy reading and speaking in front of others. In this way, he lost his sense of shame. 
Humiliation is an emotion that is too commonly experienced in schools all around the world, particularly for students from socioeconomically, ethnically or racially marginalised populations. As global and national programs promise 'education for all', and more and more young people invest their hopes in schooling, they often find their 'dreams made small' - the title of Jenny Munro's (2018) powerful study of the schooling experiences of Papuan Highlanders in Indonesia (see also Munro, 2013). Solomon Islanders rarely encounter the bald racism that Papuans suffer in secondary and tertiary schools dominated by non-Papuan Indonesians, but Munro's analysis of processes of 'belittlement' is nevertheless relevant to schooling within the independent nations of the Western Pacific. In Solomon Islands, like Papua (Munro, 2017), there is a gendered dimension to hope and humiliation in schooling. Many young men with whom I spoke expressed anger, frustration and dismay about schooling; they told me how disappointed and uncertain they were regarding their futures. Young women were also critical of English-only schooling, but they rarely seemed angry. They were far more optimistic about their futures than young men were.

Like others in the collection, this chapter draws inspiration from the work of Martha Macintyre. Across her writings, Macintyre has insisted that contemporary forms of gender inequality should be understood in the context of colonial and postcolonial histories, rather than some imagined traditional culture (see e.g. Macintyre, 2017). This approach is evident across her ethnographic work, from rural Tubetube (Macintyre, 1987, 1988), to mining compounds in Lihir (Macintyre, 2006, 2011a) and among urban working men and women (Macintyre, 1988, 2000, 2008, 2011b).

I also build on studies of contemporary masculinity in the Pacific (e.g. Biersack, 2016; Jolly, 2008), particularly work that has focused on the struggles of non-elite men who are increasingly excluded from positions of power in their own societies. These struggles have formed an ongoing concern for Laura Zimmer-Tamakoshi, who has documented intergenerational conflict and the increasingly chaotic modes of leadership that followed the decline of traditional 'big men' (Zimmer-Tamakoshi, 1997, 2016, this volume; see also Gibbs, 2016). Chapters in this volume by Deborah Gewertz and Frederick Errington and Dan Jorgensen highlight the violent behaviour in which some men engage, when faced with irrelevance or powerlessness. Fortunately, not all the emergent masculinities are so depressingly destructive of self and community. In the 
face of colonial humiliations, some Pacific men have re-embraced warrior identities (Tengan, 2008), often in the arena of sport (Calabrò, 2016). Moreover, like men all over the world, many men of the Pacific have been drawn to the gentle patriarchy of Pentecostalism, a form of Christian faith that scholars have argued is appealing to both men and women, due to the way that it curbs excesses of male power and draws men back into centre of domestic life as husband, father and head of the household (Brusco, 1995; Eves, 2016; Cox \& Macintyre, 2014).

In this chapter, I analyse gendered experiences of education in Solomon Islands, expressed through the reflections of students and young teachers involved in the Kulu Language Institute. Inequality is obviously harmful to those of lower economic means, social status and educational opportunities. Scholarly research on inequality provides a more counterintuitive insight-socioeconomic inequality is also harmful to those who are on the top of the rankings (Wilkinson \& Pickett, 2009). In the cases I discuss, young men enjoy privileged access to schooling. Until recently, parents were much more likely to pay school fees for boys rather than girls. Boys continue to undertake far less domestic work than girls and teenage boys are rarely expelled from school when they impregnate girls, nor are they burdened with the care of children born outside marriage. Yet these privileges do not necessarily benefit young men. Rather than feeling empowered, many feel worthless and unable to live up to expectations. The Kulu Language Institute has opened a path for some young men to reconceptualise their lives and envision a positive future for themselves and their communities.

\section{Education and Gender Inequality in Solomon Islands}

In Solomon Islands, and in many developing country contexts, women and girls face more significant barriers to education than their brothers, barriers poignantly illustrated by a recent report that built on the insights of adolescent girls themselves (Plan International, 2019). Most families struggle to pay for the costs of education. Where schooling opportunities are scarce, they choose to prioritise the education of boys over girls. With minimal access to contraception or sexual information, romantic relationships forged in school often lead to pregnancy, which is stigmatised and leads to young women-but not young men-being expelled from 
school. Women and girls are also subject to violence, including sexual violence, and often do not feel safe in school or while travelling to school. Girls and young women contribute far more labour-approximately 75 per cent more- to the functioning of urban and rural households than boys and young men. Despite ongoing inequity and the significant barriers to education faced by women, however, educational opportunities for women have expanded dramatically over the last generation.

Over 20 years of research on Ranongga, I have noticed shifts in attitudes among parents, who seem to be more committed to sending both daughters and sons to school. Many still worry that girls will fall pregnant if they are away from home at school. Yet there is also a sense that girls who obtain waged employment are more likely to use it to support their extended families than boys are. These shifting attitudes are evident in the life story of a woman whom I address as 'auntie'. She was the youngest of 14 children in a prominent post-War Ranonggan family and excelled in school, but her father and elder brother refused to pay her school fees. They had invested their hopes and funds in her brother and expected her to stay home and look after the family until she married and had a family. If she went to school, they reasoned, she would simply become pregnant, come home and their money would be wasted. Her mother quietly saved household money and paid her fees, allowing her to complete secondary school and then a nursing degree. 'Prove your brothers wrong,' her mother told her. This opposition to women's education did not end within this auntie's generation. When her niece wanted to continue her secondary education in the 1980s, she faced the same objections from her uncle and grandfather. Following a pattern established by her own mother, this auntie supported her niece, who is now a schoolteacher on her way to becoming a principal. Now retired from a successful professional career, this auntie mused on how wrong her father and brother had been. An elder brother who lives overseas sends money for large family endeavours, but she and her niece are the ones who have consistently used their modest salaries to support their rural kin. ${ }^{2}$

Such on-the-ground experiences combine with major shifts in policy, driven in part by aid-donor-driven agendas for increasing access to education and achieving gender equality. Recent MEHRD performance reports include close analysis of the changing levels of gender disparity,

2 Eriksen (2008, p. 80) has observed that remittances paid by educated North Ambrym women working in urban Port Vila are changing attitudes towards education for both women and girls. 
reflecting a policy commitment to closing the gap between boys' and girls' levels of schooling. As of the 2009 census, 80 per cent of children aged 6-14 were enrolled in school, an increase from less than 60 per cent in 1999 and less than 40 per cent in 1986 (Solomon Islands Statistics Office, 2012, p. xxviii, 95). During the 1970s, girls were far less likely than boys to attend school. The census indicated that 40 per cent of all women in their 50s in 2009, but only 20 per cent of all men in their 50s, had never attended school. By 2014, boys and girls participated equally in early childhood, primary and junior secondary school. Gender disparity persisted in senior secondary school: in 2014, nine girls were enrolled for every 10 boys in Years 10-12 of schooling, resulting in a Gender Parity Index (GPI) of 0.9 (MEHRD, 2015, p. 6). By 2018, girls had achieved parity with boys in Year 10; further, the GPI of 0.94 in Year 11 and 0.9 in Year 12 also signalled a trend towards equal enrolments (MEHRD, 2019, p. 22). Although more than 90 per cent of all primary and secondary students in Solomon Islands are older than the official age of enrolment, girls are slightly less likely to be over-age than boys, which suggests that they are either more likely to start on time or less likely to be held back a grade (MEHRD, 2019, p. 21). By all measures, there has been a steady and significant expansion of educational opportunities for Solomon Islander girls and women over the last generation.

The commitment to expanding basic (Years 1-9) education has meant that more students are in school for longer periods all over Solomon Islands. Due to this expansion, the cost of education has become a significant burden for nearly all Solomon Islands families. Under the fee-free basic education policy of Solomon Islands, no fees are charged for students in Years 1-9. However, school boards have implemented various kinds of registration fees or parental contributions. On Ranongga, for example, community junior secondary schools (the least prestigious level of such schools, below provincial and national secondary schools) require 'parental contributions' of SBD 1,000-1,500 (AUD 200-270). ${ }^{3}$ Senior secondary schools charge fees of several thousand Solomon Islands dollars, in addition to even greater contributions. If fees or 'contributions' are not paid, children are not permitted to attend school.

3 This is a considerable sum of money for large rural families. For context, in 2018 Solomon Islands GNI was approximately SBD 19,000 (USD 2,370), according to World Bank Data (data.worldbank. org/country/SB). Parental contributions alone approach 10 per cent of GNI, without including travel or school supplies, and net income is lower than the national GNI in rural areas. 
It is not clear that the money spent to keep youth in classrooms for longer periods has positive results in terms of employability, which is the primary motivation that many parents and students see for education. Jobs that required Year 9 education 20 years ago now require a Year 12 education, and today's Year 12 graduates are rarely able to find work. Credential inflation is obviously one aspect of the problem (Dore, 1976). But there also appears to be a decline in the quality of schooling. High school graduates today are said to be less well-educated than their fathers or grandfathers, who only completed primary school. MEHRD reports reveal better results for numeracy than literacy, but generally low levels of achievement; at Year 6 in 2010, 40 per cent of students reached 'moderate' mastery, while 60 per cent demonstrated 'minor', 'minimal' or no 'mastery' (MEHRD, 2013, pp. 31-39). This data from standardised testing resonates with anecdotal evidence that many students are not achieving even basic literacy with six or more years of schooling. On my most recent visit to Ranongga, teachers at the Kulu Language Institute told me of students who came to the Kulu Institute entirely illiterate-unable even to write their namesdespite completing nine years of school. They lamented this wasted time and wondered about the long-term effects of such prolonged experiences of failure.

Observers have linked the expansion of access to schooling to a decline in quality, often blaming inadequate teacher training or resourcing (Watson-Gegeo, 1987; Watson-Gegeo \& Gegeo, 1992a, 1992b). Beyond problems of curriculum or teacher training, schooling is made more complex because authority and oversight are vested in provinces, which have limited capacity and minimal funding to implement goals (Maebuta, 2013, p. 124). Moreover, despite the rhetorical emphasis on the need for mass education, government expenditure is significantly skewed towards tertiary education (Whalan, 2011, p. 242) - the realm in which women and rural people of both genders are most disadvantaged. Perhaps the greatest overall problem with schooling, however, is its orientation towards narrowly economic outcomes. Even if the education system were more effective in teaching basic numeracy and literacy, it would not fulfil the promise of salaried employment, given that there are far more graduates than there are jobs available. 
Goi Is.

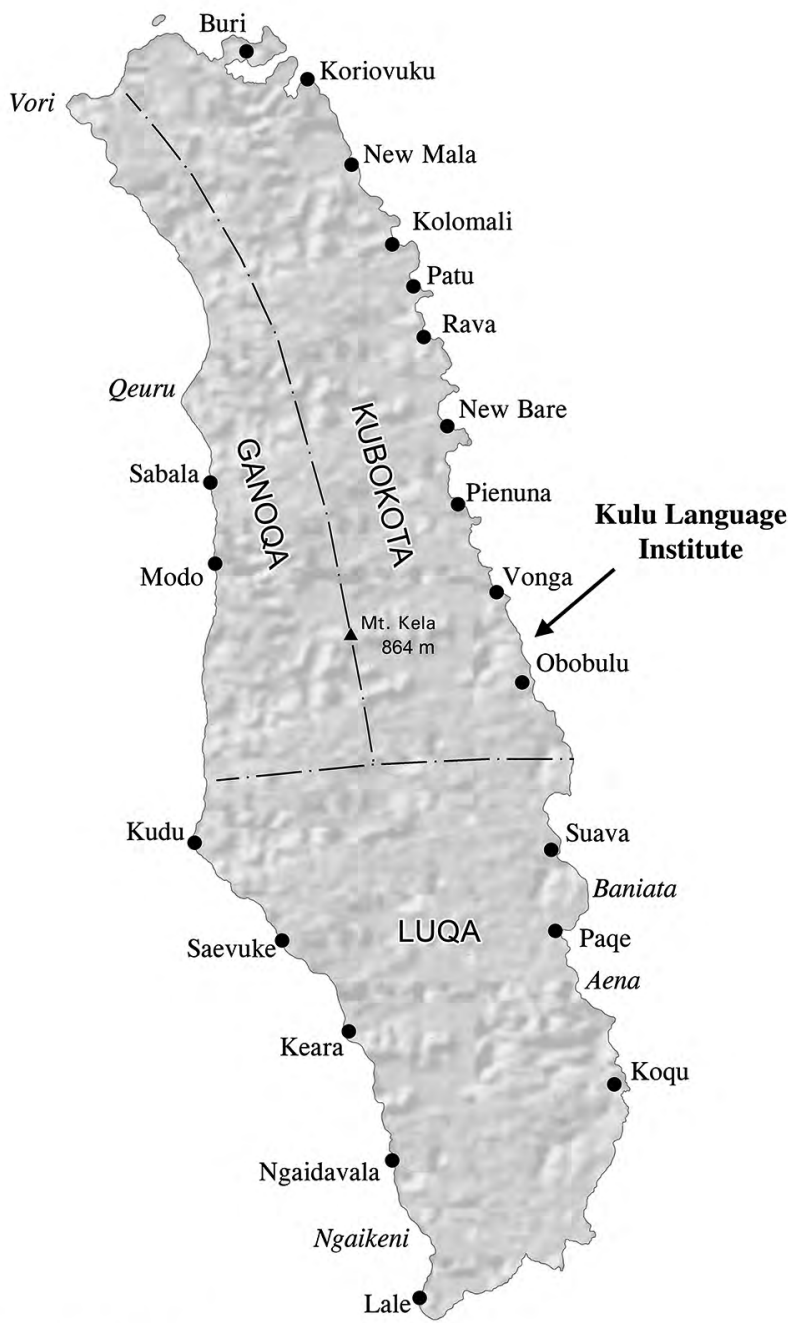

\section{Ranongga Is land}

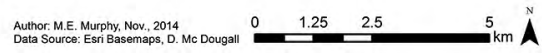

Figure 1: Ranongga Island.

Source: Map by M. E. Murphy. Data source: Esri Basemaps, D. McDougall. 
With the massification of schooling, lineages and extended families no longer pool resources to support a single student in further studies. Today, it is mainly parents who struggle to find money for their children to attend school, raising money themselves or approaching the local member of parliament to pay the fees from his constituency development fund. Parents and politicians alike seem willing to support both girls and boys in education. Educational achievement in the 1960s and 1970s, when few men and even fewer women finished primary school, allowed the previous generation of men to move into positions of respect and authority. Despite ongoing inequality in access to upper secondary and tertiary education for women, it is true that young women today enjoy far more possibilities for advanced schooling than their mothers and grandmothers did. For young men today, education and career possibilities seem to be contracting at the same time that men seem to be playing a less important role in domestic life-I return to this point below.

\section{The Kulu Language Institute of Ranongga}

The Kulu Language Institute takes its name from the two languages spoken on Ranongga. Luqa is spoken by approximately 3,900 people in the southern half of the island and Kubokota is spoken by approximately 3,400 people in the northern half (see Figure 1). ${ }^{4}$ When the first Luqa grammar teachers began in the late 1990s and early 2000s, classes were convened in community halls, under tents or simply in the shade of trees. Today, the Kulu Language Institute has a campus situated on a beautiful stretch of coastal land. Over the past five years, the Kulu school has grown exponentially. By 2018, some 1,500 adults or teenagers—approximately 20 per cent of the entire population of Ranongga - had undertaken at least one workshop or class on Luqa grammar (Zobule, 2018).

I have followed this movement since its beginnings (McDougall, 2012). On a visit back to Ranongga in 2016, I observed how it had grown and began conversations with the director of the Kulu Institute, Dr Alpheaus

4 The ISO 639-3 codes are 'lga' for Luqa and 'ghn' for Kubokota, which is also known in the literature as Ghanongga, Ganoqa or Ghanoga language. For further details about Kubokota, see Chambers (2009). Estimates for 2018 speaker populations are based on the 2009 Solomon Islands population census tabulated by ward with 541 people for North Ranongga, 2,514 for Central Ranongga and 3,305 for South Ranongga, with a two per cent annual growth rate for the province. Kubokota is spoken primarily in North and Central Ranongga and Luqa in South Ranongga (Solomon Islands Statistics Office, 2012). 
Graham Zobule, about interviewing students, teachers and community members to understand its apparent success and potential challenges. In November 2017, I conducted more than 50 interviews in Honiara and on Ranongga and also observed a week of classes at the Kulu Institute. In 2019, I began work in digitising legacy materials from Ranongga, including my own field recordings, recordings from the now-disbanded provincial culture office and stories produced by Kulu Language Institute. ${ }^{5}$ Zobule is a partner in this Endangered Languages Documentation Project, which involves Kulu staff who are transcribing the materials and beginning to produce new audio recordings of people talking about local values and histories. In August 2019, I worked with colleagues from Australian universities, in addition to Zobule and his colleagues in Ranongga and Honiara, to facilitate public lectures and a week-long workshop on vernacular languages (McDougall, 2019).

The Kulu Language Institute curriculum presents a challenging exploration of the structure of local language-it differs from other vernacular language initiatives around the country that teach very young children how to associate letters and sounds in their own language before quickly moving on to English (Burton, 2012; Cox, 2017; Glasgow, Ha'amori, Daiwo \& Masala, 2011). Through dialogue with the first generation of Luqa grammar teachers, Zobule developed a corpus of materials, including eight textbooks and thousands of pages of text, that develops a new vernacular metalanguage for describing the grammar of Luqa. This metalanguage metaphorically expands existing vocabulary for family relationships, the structure of plants and words for cutting, grouping and searching.

Four texts comprise the core sequence of classes that are regularly offered at the Kulu Institute (Zobule, 2016). Book 1, titled 'Reading Luqa language', focuses on phonology, the idea of syllables and the meaning of words. Reading comprehension exercises focus on stories written by former students. Book 2 is titled 'The structure of words' and is focused on parts of speech-understanding how words function differently depending upon their relationship with other words in the sentence. Book 3, 'The structure of sentences', explores the structure of noun phrases, clauses and sentences. Book 4, 'Structure of complete writings', focuses on text composition and analysis. In addition to these four core

5 Recordings and texts from Ranongga, Solomon Islands. elar.soas.ac.uk/Collection/MPI1314450. Funded by an Endangered Language Documentation Program Legacy Materials Grant. 
courses, Zobule has produced a guide to teaching, illustrated alphabet books in both Luqa and Kubokota and a preliminary course for adults or children with no literacy. Most of the instruction in the Kulu Institute is in and about Luqa; there is also a Kubokota version of Book 1. There are also two books on the grammar of English. Students are not admitted to study English grammar classes until they have completed the sequence in Luqa grammar.

Depending on the level of the class, Kulu classes last between five and 10 days, with six hours of instruction per day. The first-level classes are held in villages wherever and whenever there is sufficient demand. More advanced classes (Luqa Books 2-4 and English) are held on the Kulu campus. Kulu students pay modest fees of SBD 200-400 (AUD 35-70), depending on the length of the course. The fees cover the textbooks (bound photocopies of up to 200 pages), accommodation and food; they also generate a small quantity of revenue to support the Kulu school. In 2017, Kulu teachers began to receive a small payment of SBD 50 (less than AUD 10) for a week-long course. Zobule's wife, Sanny Zobule-who runs their family business, a low-cost rest house in Honiara-financially supports Kulu staff to pursue further training with her husband in Honiara.

The work of the Kulu Language Institute originated during the years when Zobule was leading the Luqa translation of the New Testament. When the first draft of the Gospel of Mark was produced in 1998, he realised that many Ranonggans could not read it; either they had never learned to read or they were unable to read their own spoken vernacular. Zobule's cousin John Tengana began teaching literacy to people of Saevuke village. Saevuke had never had a primary school and its people were ridiculed for their ignorance. Tengana found that Saevuke people were confused by English words such as 'consonant' and 'vowel'. He pressed Zobule to produce Luqa language terms that people would understand. In late 2000, a workshop on Luqa grammar was held in Saevuke, which drew people from all around the island into the study of grammar, including Izikeli Moata of Kudu village. When I interviewed him in 2017, Izikeli recalled that he was surprised by the way the language worked-it captured his imagination. He began to teach alongside Tengana, using materials that Zobule was developing, and the two were eventually joined by Danstone Beck of Paqe village. Zobule calls these men the 'pioneers' of the Kulu 
Institute (see Figure 2). They taught Luqa throughout the 2000s, while Zobule was overseas, completing a second Master's degree and a $\mathrm{PhD}$ in theology.

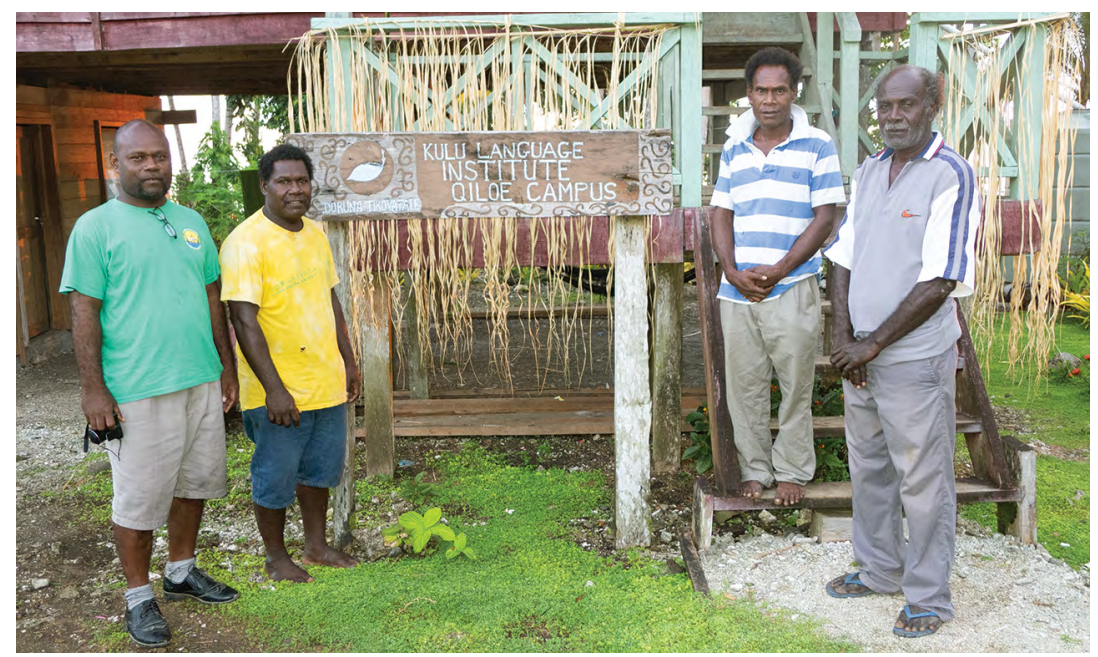

Figure 2: Kulu Director Dr Alpheaus Zobule, with head teacher Izikeli Moata, founding teacher John Tengana and principal Stephen Buka (November 2017).

Source: Photo by Debra McDougall.

In the 2000s, few Ranonngans perceived the value in formally studying a language that they already knew and that would not contribute to their socioeconomic mobility; the fact that the teaching of Luqa grammar persisted after the translation was completed is due to the tenacity of Tengana, Danstone and Izikeli. Tengana attended meetings of the Ranongga circuit of the United Church and inserted workshops on Luqa grammar into the annual schedule. In the absence of funding for transport, the three men walked for hours across and around the island, to deliver the courses. Often hungry and exhausted, they left their wives behind to look after children, garden and generate household income. Danstone was a builder by trade and he used his own funds to photocopy the Luqa materials, so that they would have enough copies for each student to read one during class. Danstone took up residence for nearly a decade in the hamlet of Qiloe to teach Luqa grammar, a relationship that eventually led to the gift of land to the Kulu Institute, which 'anchored' it and provided it with a place in which to grow. Izikeli was serving as head teacher when I stayed on the Kulu campus in 2017. 


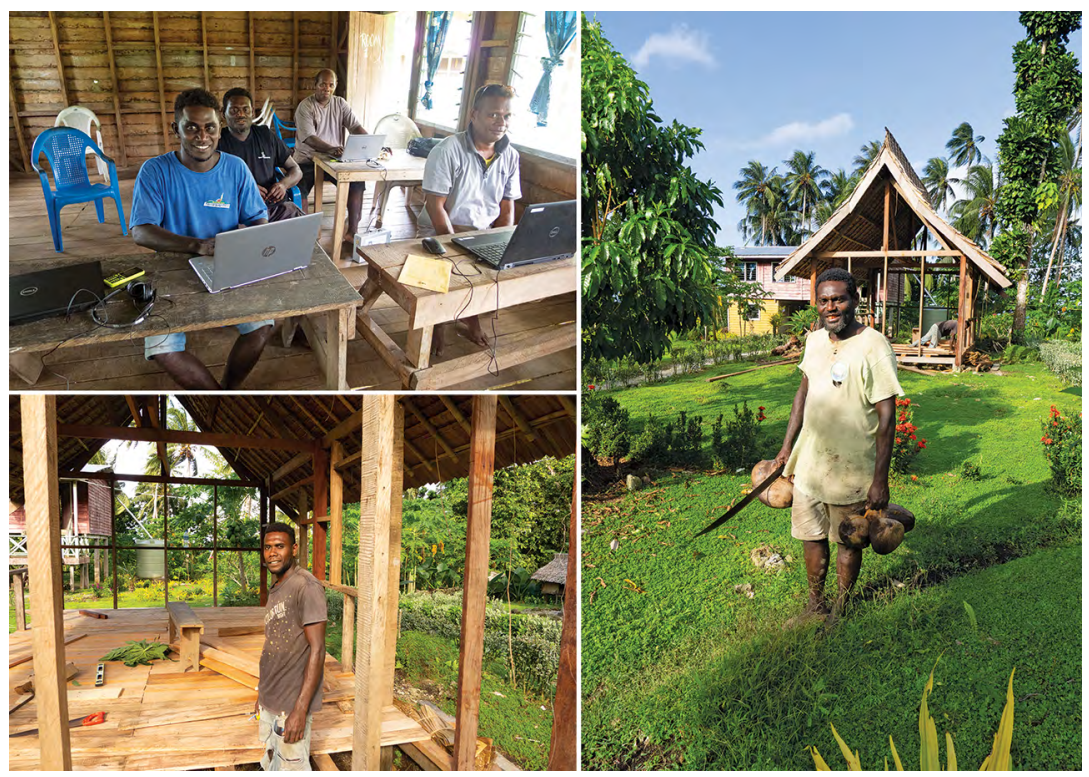

Figure 3: Kulu teachers (clockwise from top left): John Poa Lokapitu (Account Manager) and Aldrin Apusae, Samuel Bakson (Deputy Principal) and Nathan Manoa (Grounds Manager) (September 2019).

Source: Photos by Debra McDougall.

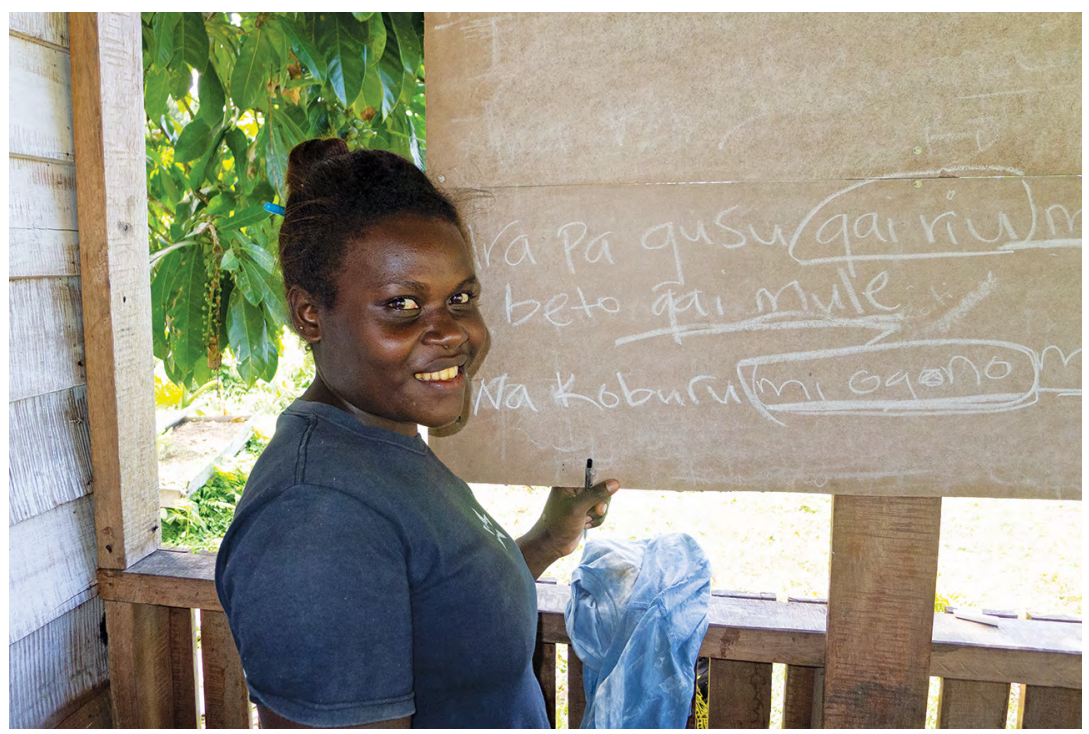

Figure 4: Radence Philipi, apprentice teacher (September 2019).

Source: Photo by Debra McDougall. 
It is not a coincidence that the pioneers of the Kulu Institute were men. These were not ordinary men-few would have made the sacrifices that Tengana, Izikeli and Danstone did. However, even if a Ranonggan woman were to have become as passionate about Luqa grammar as these three, I doubt that she would have been given permission to leave her husband and children behind in the way that these three men did. As of 2019, all leadership positions in the Kulu Institute-principal, deputy principal, finance manager and grounds manager-are held by men (see Figure 3). Most teachers and apprentice teachers are also men, but this is slowly changing. The first female teacher is an unmarried woman now in her 30s; in 2019, she was one of two women undertaking further study in Honiara with Dr Zobule. In September 2019, one of the two apprentices at the Kulu Institute was a young woman (see Figure 4).

Although they do not hold formal leadership positions, women are essential for the everyday running of the school. I have already mentioned Sanny Zobule's critical behind-the-scenes financial support of the school, the teachers and her husband's scholarly activities. Each time I have visited the Kulu campus, the principal and teacher's wives have organised meals for students and visitors. When large numbers of students enrol in Kulu classes during school holiday time, women from nearby hamlets are paid a small fee to assist with cooking. More often, they voluntarily contribute cooked food and garden produce, particularly when the Kulu school hosts visitors. Not all domestic work is done by women-both male and female students are rostered to assist with meal preparation, including late-night shifts baking bread for morning classes, and all students work in the school gardens in the afternoons. Male teachers and apprentices do construction work; they saw and carry timber and other housing materials and construct classrooms and staff houses.

In the very early days of the movement, men were the primary attendees. In the first Luqa grammar workshop held in 2000, for example, I was one of three women present and the only one who had travelled from beyond Saevuke. Most early students were men intending to study theology to become ministers in the United Church, who hoped that learning Luqa grammar would help them understand the new Luqa New Testament and understand English. As the movement grew and spread, women joined in the workshops offered in their villages. Today, young women enrol in the school in slightly higher numbers than young men. 


\section{Gendered Ambitions}

The massive growth in attendee numbers in recent years is due almost entirely to an influx of youth who are currently enrolled in junior or senior secondary school, who have completed secondary school, or have quit or been forced out of school due to failing to achieve adequate exam results for entry into higher levels of schooling, failing to pay school fees or other circumstances. According to attendance lists and teachers' reflections, female and male students attend in approximately equal numbers. Their reasons for enrolling are simple-they expect it to help them in their formal studies, particularly the study of English. Increasing numbers of trained primary and secondary teachers are also attending the Kulu school, because they have witnessed these effects on their students. ${ }^{6}$

The young men and women who had completed all or some senior high school were critical of the fact that the instruction started with English. One young woman said that learning English grammar in school made learning Luqa grammar easier, but most of the others focused on the negative effects of doing things 'backwards'. Even those who were relatively successful in passing highly competitive exams to move onto higher grades said that everything was 'fuzzy' in normal school, whereas things were clear at the Kulu Institute. Several interviewees likened school learning to poorly prepared meals. As the first female Kulu Language Institute teacher told me, 'they give raw food to children, so they just eat it uncooked'. Some spoke of unripe fruit, and others described it as a jumbled pile, contrasting it with the Kulu curriculum, in which everything is laid out carefully, as one might lay out a feast. Many contrasted the rote learning of school to the more creative work in Kulu, remarking on the way that Kulu teachers 'played with the language' to understand and explain how it works.

Young women who were currently enrolled in secondary school mentioned that they hoped that studying Luqa would allow them to understand the Bible better and use language effectively in all realms of life. Nevertheless, it was clear that their primary goal was learning Luqa to

6 At a September 2019 gathering at Qiloe, Zobule addressed the increasing instrumentalisation of the Kulu Institute. Although he was pleased that the school was helping young people, he suggested that everyone, especially adults, should be trying to dig deeper into their own language. The gathering marked the beginning of a new branch of work at the institute-documenting and strengthening local values that are worth preserving in the face of changing ways of life. 
succeed in school. One student told me how happy she was when she got to the English grammar section of the Year 11 exam-she found it easy because she had studied with the Kubokota, Luqa and English grammar books. When I asked them about their aspirations, each spoke of finishing secondary school and doing further training - one aspired to study law, another computer work, another teaching and a few were unsure. They also praised the Kulu curriculum for its coherence and seemed to find the intensive format of the Luqa grammar classes helpful. One secondary school student told me that, in school, they skip back and forth between subjects, with too much time between English lessons.

Although they were critical of conventional schooling, none of these young women was as scathing in their reflections as many of the young men. For example, none of them spoke of school ruining them in the way that the young man quoted at the start of this chapter did. This youth was speaking about something far deeper than mere academic failure-schooling seemed to have inflicted an injury to his very sense of self. The Luqa term I have glossed here as 'ruin' is ngangulu. Like the Pijin tem spoil, ngangulu refers to both physical damage and the metaphysical destruction of a curse or sorcery. Other young men told me that they felt that school had tricked or cheated them. Nearly every young man interviewed recalled the way that they felt ashamed of themselves and were unable to stand in front of a group to speak or read. They spoke not only of how much clearer and straightforward the Kulu curriculum was but also the way it has given them confidence. Several of the young men who became apprentice teachers or teachers in the Kulu school recounted how they completed secondary school with no sense of purpose. Even where they succeeded in school, they felt lost and useless; they were ashamed that they had let their families down because they had not found employment.

One young Kulu teacher said that he took a Kulu class only because his brother-in-law suggested it. He reluctantly asked his grandfather for school fees. At the time, he was mocked for studying his own languagepeople laughed at him for 'going back to kindergarten' after completing secondary school and asked why he was not doing something useful with his life. Yet he persisted, apprenticing himself to Tengana, Izikeli and Danstone and eventually becoming a teacher in his own right. Another teacher told me of his circuitous schooling journey and the feeling that he was disappointing his family, who had valued education highly for two generations. He eventually completed vocational schooling in marine 
training and worked on ships for several years before returning to his wife's village to be a 'farmer'. Still, he thirsted for some other kind of work and found his calling in the Kulu school, which he first attended simply because it was only a few hundred metres from his house. He was overjoyed when Zobule invited him to become an apprentice teacher. Another young man, a student at the Kulu Institute in 2017, told me of being unable to sit his Year 11 exam because his family could not pay the fee. He thought his future was over, but an uncle has sponsored him to study Luqa grammar, and he now sees work for himself in teaching kindergarten.

These young men spoke of profound personal transformation, a reorientation that was moral and spiritual as well as intellectual. One young man told me that he would probably be in prison if it were not for the Kulu school-before he studied Luqa grammar, he was a thief and smoked marijuana. Another had always been successful in school and had attended a prestigious provincial secondary school. Despite his success, he never felt any confidence in himself:

It was as though I was chasing the shadow of something, but I couldn't actually grab the thing itself. I didn't know what I was doing, or what school was doing for me. It was though I was flailing around on the surface of the sea; I didn't know anything. Imagine you are on the surface of the sea and grab at a dry coconut floating past. If you don't get a good grip, it slips away. When I came to Kulu and finished the classes, it was as if I had dug down under the surface of the ground. Now I'm able to dig out something strong. It is as if I'm digging under the surface of the earth.

When he completed the vernacular language curriculum, he felt transformed: 'it was as though I was freed from prison'.

Who could have predicted that studying grammar would have such a profound effect on young men's sense of self and worth? Over and over, in my interviews and conversations with young men, they told me not only of their intellectual failures but also moral failings: drinking, stealing and spending all their money on betelnut or cigarettes. Somehow-and no one could really articulate precisely how this was the case-the study of a local language shifted their entire outlook on life. It made them stop feeling like failures and made them respect themselves. 


\section{Dispensable Men?}

In a volume on how myths of matriarchy may paradoxically support male political dominance, Macintyre (1988) examined two forms of myth on matrilineal Tubetube. The first genre of myth depicts a woman born of sea creatures who leaves her mother to live with a husband. She is ultimately betrayed by her in-laws and abandons her husband to return to the sea. The second type of myth depicts quasi-human husbands who are lazy or stupid and are killed after they impregnate their wives. These 'mythic demonstrations of inadequacies of husbands', Macintyre argued, 'provide a moral basis for a matrilineally constructed social order that depends upon the unity of brothers and sisters' (1988, p. 188). In Tubetube reality, married couples move back and forth between husbands' and wives' families, with burdensome labour obligations to both sides of the family and complex sets of affinal and patrilateral exchanges constituting the flow of social life. In Tubetube myth, the matrilineal social order reproduces itself. Husbands are, ultimately, dispensable.

As in Tubetube and much of island Melanesia, Ranonggan clan identities are traced through mothers, as are deep and existential connections to ancestral land. Women, rather than men, are remembered as apical ancestors in genealogies. Oral historical accounts of events of the late nineteenth century and early twentieth century suggest that women played important roles in arranging marriages, allocating land and welcoming outsiders ashore (McDougall, 2016, pp. 64-91). Myths and humorous folk tales focus on sibling relationships, often depicting what happens when brothers and sisters do not properly take care of one another. Sisters and brothers were understood to be metaphysically linked - a woman who died in childbirth, like a man who died in warfare, became a 'bad ghost' and the moral infractions of a cross-sex sibling were seen as the cause of such a calamity. Despite underlying ideologies of matriliny, and this emphasis on cross-sex sibling complementarity, men possess more political power than women. As Macintyre (1987) argued was the case in Tubetube, this differential power seems to have once been strongly linked to men's engagement in warfare; men held a monopoly on physical violence.

Over the course of the twentieth century, a more straightforward kind of patriarchy emerged in the Western Solomons. Churches recognised fathers and husbands as heads of families and governments recognised brothers 
(but not their sisters) as leaders of matrilineal clans. Such developments arguably weakened the constitutive relations between sisters and brothers and undermined the cognatic ties among their descendants. The changing political economy has also shaped gendered identities and ownership. From the 1930 s to the 1960 s, when copra production formed the backbone of the colonial economy, patrilineal inheritance patterns seemed to dominate-coconut plantations belonged to individual men, rather than their matrilineages. When copra prices plummeted in the 1980s, however, things changed. Ranonggan families turned to market gardening to generate cash income. Families work together on both copra production and market gardening. Whereas copra plantations were identified as male property, gardens are mostly identified as belonging to women, and marketing is done entirely by women. Commercial logging commenced on Ranongga's steep hillsides only after more profitable forests elsewhere were exhausted. Battles over landownership in the context of resource capitalism are always fought in the name of matrilineal clans (so-called 'tribes'). Though matriliny lies at the centre of these battles, women are excluded; only men speak for their clans in court and in negotiations with companies. However, rather than bolstering men's authority, involvement in the sordid politics of logging has undermined their moral authority in all other realms. Women are taking on more central roles in the leadership of families and communities and even stepping into neo-traditional 'chief' roles that had always been seen as male (McDougall, 2014).

Macintyre did not directly relate the puzzles of matriliny to the challenges of contemporary PNG women, but her ethnographic studies of educated and employed women seemed to suggest that they are enacting the Tubetube mythic vision of the 'dispensable husband'. She argued that women in mining experience the classic 'double burden' with a vengeance, usually maintaining large gardens while also holding full-time work (Macintyre, 2006). Yet they use the freedom that their wages have given them to break the bonds they find most constraining-particularly relationships with abusive, neglectful or unfaithful husbands. For such women, 'money changes everything' (Macintyre, 2011b). A degree of economic independence has allowed them to reject bonds of marriage to husbands who have been taught for generations that they have the God- and custom-given right to dominate their wives (see also ZimmerTamakoshi, 1998; Spark, 2011, 2017). Such independent women are often savagely critiqued-accused of embracing global human rights discourses and the decadent individualist lifestyles that go with them 
(Macintyre, 2000, 2012; see also Jolly, 1996; Taylor, 2008). Clearly, though, these women are reshaping, rather than rejecting, the networks of kin relationships that sustain them; they invest heavily in their own children as well as nieces and nephews, an investment that often takes the form of paying school fees.

As more women choose not to marry, marriage is increasingly portrayed as the quintessentially traditional social institution. In reality, marriage has been undergoing continuous change for decades in both rural and urban areas of the Western Pacific (see chapters in Marksbury, 1993). In Ranongga in the late 1990s, when I began my research, premarital sexual activity was common, but when women fell pregnant, marriage was usually arranged. Increasingly, young women have children and are not compelled to marry. Some children are looked after by their grandmothers, while mothers may be away working or studying or even living with a new husband. In the family that I have lived with most often on Ranongga, the generation of women now in their twenties all have children, but few have any relationship with the father of the children. The fathers seem to have no responsibility for the children, and young men seem increasingly inessential in domestic life.

Ranonggans speak of marriage as 'sitting down well'. Despite the fact that not all marriages allow partners to 'sit down well,' the metaphor aptly captures the sense of stability that is lost as marriage declines as a social institution. Prototypically, a husband clears the land for the garden and builds a house for his wife and children; the lack of anyone to help with such work is what unmarried Ranonggan women, and married women whose husbands are absent or neglectful, complain about. Nevertheless, gardening and care of children are primarily seen as the work of women. When women are unmarried, they perform this work within their natal families, continuing to be linked to kin and family. The state of not 'sitting down well' seems to have a more existentially powerful effect on young men, who have no paternal obligations and far fewer responsibilities to their natal families than young women. They are free but also detached-perhaps even dispensable. It seems to me that some of the malaise of young Ranonggan men I spoke to originates in this feeling of being dispensable. 


\section{Conclusion}

During my most recent trip to Ranongga, I spent a weekend in the village that has become home to me-Pienuna, approximately a 45-minute walk from the Kulu Institute. Twice on Saturday night, my household was awakened by the howls of young men, drunk on home-brewed alcohol. They walked through the hamlet, swearing in Kubokota and English and gathering on the shore that is still referred to as the chief's landing place. Drunken behaviour of this sort is a breach of rules of interaction in Ranongga, where quiet indirect discourse - not shouting or haranguingcharacterises public speech. In all my years living in Pienuna, I had only heard such outbursts a handful of times, and they were invariably followed by some sort of formal conflict resolution. Requests for compensation for swearing were often combined with some airing of the underlying problems that had caused the outbursts. Now, I learned, the young men drank and behaved in this way every weekend. No one even tried to stop them.

Young Ranonggan women often feel controlled-their labour is demanded and their sexuality is policed. But they rarely feel useless in the way that young men often seem to. The young men running amok in Pienuna enjoy much greater freedom of movement and behaviour than their sisters; however, this freedom counts for little when they cannot envision a worthwhile life. Their self-destructive behaviour seems like the 'negative agency' that Holly Wardlow (2006) discussed in relation to Huli women. Feeling manipulated, disrespected and disregarded by their natal families, Huli women engaged in casual sexual encounters for money or pleasure and, in the process, they ruined their reproductive capacity- the quality that their male relatives valued most. Might the performatively bad behaviour of young Ranonggan men also be a 'fuck you' (to quote one of the young men yelling in Pienuna village) to their kin and community, who make them feel worthless?

One way to understand the power of the Kulu Institute is to place it within the context of other movements that have promised to transform the lives of people of the Western Pacific. Perhaps the most powerful among these are charismatic Christian revival movements. I have long been interested in the gendered dynamics of these religious movements in Solomon Islands. They seem to provide not only a ground upon which women are able to organise and emerge as collective actors but 
also a vehicle for new kinds of masculine self-formation (McDougall, 2003, 2009, 2013, 2014; see also Maggio, 2016). Men, in particular, become passionate about religious teachings because they promise a way that they can transform their own lives from the inside out. I have been struck by the similarity between the kinds of testimonies I have heard as part of my research on new forms of Christianity and the testimony of young men involved in the Kulu Institute. Similar stories of profound transformation emerge in Nick Bainton's (2011) study of the Personal Viability movement in Lihir and beyond and John Cox's (2018) research on how fast money schemes continue to attract people, often through evangelical Christian networks.

The Kulu Language Institute resonates with other grassroots social movements that have re-valued local ways of life in periods of rapid social, economic and political change. One such movement has been thriving in Ranongga's nearest neighbour - the 'Simbo for Change' movement focuses on local livelihoods and has inspired a 'revitalised ethic of care for the island' (Suti, Hoatson, Tafunai \& Cox, 2020). Many such movements have centred on what is known in neo-Melanesian languages as kastom. This term embodies a sense of opposition to European or Western forms of religion, politics or economic life; as David Akin (2013) has observed, kastom evokes a continuity with the past that is intended to assert dignity and the right of self-determination in the face of powerful outside forces. The materials of the Kulu Institute are devoid of any reference to kastom, nor is there much explicit discussion of the importance of preserving Luqa language or Ranonggan culture. Yet the very process of analysing vernacular language taps into a sense of continuity with the past, making young men like those I have quoted feel 'anchored' in solid ground (McDougall \& Zobule, forthcoming).

It seems odd that studying grammar could have such a profound effect on the moral and emotional lives of young people. Unlike words of a language, grammar is not something that people often consciously reflect upon. For many, the power of the study of grammar comes from the way it enables them to move across languages, using insights and analytical skills that have been built up in a language they know to better master English. For some students, the process has also opened up a new understanding of broader sociopolitical and educational structure, allowing them to see that what they imagined as their own personal failures were, in fact, flaws in the system. 


\section{References}

Akin, D. W. (2013). Colonialism, Maasina rule and the origins of Malaitan kastom. Honolulu, HI: University of Hawai'i Press.

Bainton, N. A. (2011). Are you viable? Personal avarice, collective antagonism and grassroots development in Melanesia. In M. Patterson \& M. Macintyre (Eds), Managing modernity in the Western Pacific (pp. 231-259). St Lucia, Qld: University of Queensland Press.

Ball, J. (2011). Enhancing learning of children from diverse language backgrounds: Mother tongue-based bilingual or multilingual education in the early years. Paris, France: UNESCO. Retrieved from unesdoc.unesco.org/ark:/48223/ pf0000212270.locale $=$ en

Banivanua-Mar, T. (2016). Decolonisation and the Pacific: Indigenous globalisation and the ends of empire. Cambridge, England: Cambridge University Press.

Biersack, A. (2016). Introduction: Emergent masculinities in the Pacific. The Asia Pacific Journal of Anthropology, 17(3-4), 197-212. doi.org/10.1080/144422 13.2016.1186215

Brusco, E. (1995). The reformation of machismo: Evangelical conversion and gender in Colombia. Austin, TX: University of Texas Press.

Burton, L. J. (2012). Building on living traditions: Early childhood education and culture in Solomon Islands. Current Issues in Comparative Education, 15(1), 157-175.

Calabrò, D. G. (2016). Once were warriors, now are rugby players? Control and agency in the historical trajectory of the Māori formulations of masculinity in rugby. The Asia Pacific Journal of Anthropology, 17(3-4), 231-249. doi.org/ 10.1080/14442213.2016.1191530

Chambers, M. R. (2009). Which Way Is up? Motion Verbs and Paths of Motion in Kubokota, an Austronesian Language of the Solomon Islands (Unpublished doctoral thesis). Endangered Languages Academic Programme, School of Oriental and African Studies, University of London.

Cox, J. (2017). Kindy and grassroots gender transformations in Solomon Islands. In M. Macintyre \& C. Spark (Eds), Transformations of gender in Melanesia (pp. 69-93). Acton, ACT: ANU Press. doi.org/10.22459/TGM.02.2017

Cox, J. (2018). Fast money schemes: Hope and deception in Papua New Guinea. Bloomington, IN: Indiana University Press.

Cox, J. \& Macintyre, M. (2014). Christian marriage, money scams and Melanesian social imaginaries. Oceania, 84(2), 138-157. 
Devette-Chee, K. (2015). Attitudes toward the use of Tok Pisin and Tolai as languages of instruction in lower primary schools in Kokopo, East New Britain Province, Papua New Guinea. Language and Linguistics in Melanesia, 33(2), 16-34.

Dore, R. (1976). The diploma disease: Education, qualification and development. Berkeley, CA: University of California Press.

Eriksen, A. (2008). Gender, Christianity and change in Vanuatu: An analysis of social movements in North Ambrym. Aldershot, England: Ashgate.

Eves, R. (2016). Reforming men: Pentecostalism and masculinity in Papua New Guinea. The Australian Journal of Anthropology, 27(2), 244-259. doi.org/ 10.1111/taja.12196

Gegeo, D. W. \& Watson-Gegeo, K. A. (2012). The critical villager revisited: Continuing transformations of language and education in Solomon Islands. In J. W. Tollefson (Ed.), Language policies in education (pp. 245-264). London, England: Routledge.

Gibbs, P. (2016). I could be the last man: Changing masculinities in Enga society. The Asia Pacific Journal of Anthropology, 17(3-4), 324-341.

Glasgow, A., Ha'amori, B., Daiwo, J. \& Masala, V. (2011). The Solomon Islands' initiatives to support and enhance the use of vernaculars in early childhood education. Languages \& Linguistics in Melanesia, 29, 86-94.

Jolly, M. (1996). 'Woman ikat raet long human raet o no?' Women's rights, human rights and domestic violence in Vanuatu. Feminist Review, 52(1), 169-190. doi.org/10.2307/1395780

Jolly, M. (2008). Moving masculinities: Memories and bodies across Oceania. The Contemporary Pacific, 20(1), 1-24. doi.org/10.1353/cp.2008.0010

Jourdan, C. (2013). Pijin at school in Solomon Islands: Language ideologies and the nation. Current Issues in Language Planning, 14(2), 270-282.

Litteral, R. (2015). Changes in mother tongue education policy in Papua New Guinea. Language and Linguistics in Melanesia, 33(2), 93-99.

Lo Bianco, J. (2015). Multilingual education across Oceania. In W. E, Wright, S. Boun \& O. Garcia (Eds), The handbook of bilingual and multilingual education (pp. 604-617). Hoboken, NJ: Wiley.

Macintyre, M. (1987). Flying witches and leaping warriors: Supernatural origins of power and matrilineal authority in Tubetube society. In M. Strathern (Ed.), Dealing with inequality: Analysing gender relations in Melanesia and beyond (pp. 207-229). Cambridge, England: Cambridge University Press. 
Macintyre, M. (1988). The unhappy wife and the dispensable husband: Myths of a matrilineal order. In D. Gewertz (Ed.), The myth of matriarchy reconsidered (pp. 185-195). Sydney, NSW: Oceania Monograph Series.

Macintyre, M. (2000). 'Hear us, women of Papua New Guinea!': Melanesian women and human rights. In A. Hilsdon, M. Macintyre, V. Mackie \& M. Stivens (Eds), Human rights and gender politics: Perspectives on the Asia-Pacific region (pp. 147-171). London, England: Routledge.

Macintyre, M. (2006). Women working in the mining industry in Papua New Guinea: A case study from Lihir. In K. Lahiri-Dutt \& M. Macintyre (Eds), Women miners in developing countries: Pit women and others (pp. 131-44). Aldershot, England: Ashgate.

Macintyre, M. (2008). Police and thieves, gunmen and drunks: Problems with men and problems with society in Papua New Guinea. The Australian Journal of Anthropology, 19(2), 179-193.

Macintyre, M. (2011a). Modernity, gender and mining: Experiences from Papua New Guinea. In K. Lahiri-Dutt (Ed.), Gendering the field: Towards sustainable livelihoods for mining communities (pp. 21-32). Acton, ACT: ANU E Press. doi.org/10.22459/GF.03.2011

Macintyre, M. (2011b). 'Money changes everything': Papua New Guinean women in the modern economy. In M. Patterson \& M. Macintyre (Eds), Managing modernity in the Western Pacific (pp. 90-120). St Lucia, Qld: University of Queensland Press.

Macintyre, M. (2012). Gender violence in Melanesia and the problem of Millennium Development Goal No. 3. In M. Jolly \& C. Stewart (Eds), Engendering violence in Papua New Guinea (pp. 239-266). Canberra, ACT: ANU E Press. doi.org/10.22459/EVPNG.07.2012

Macintyre, M. (2017). Introduction: Flux and change in Melanesian gender relations. In M. Macintyre \& C. Spark (Eds), Transformations of gender in Melanesia (pp. 1-21). Canberra, ACT: ANU Press. doi.org/10.22459/TGM. 02.2017

Maebuta, J. (2013). Solomon Islands: Adaptive leadership strategies in schools. In S. R. P. Clarke \& T. A. O’Donoghue (Eds), School level leadership in postconflict societies the importance of context (pp. 110-126). London, England: Routledge.

Maggio, R. (2016). 'My wife converted me': Gendered values and gendered conversion in Pentecostal households in Honiara, Solomon Islands. The Australian Journal of Anthropology, 27(2), 168-184. doi.org/10.1111/ taja. 12192 
Marksbury, R. A. (1993). The business of marriage: Transformations in Oceanic matrimony. Pittsburgh, PA: University of Pittsburgh Press.

McDougall, D. (2009). Becoming sinless: Converting to Islam in the Christian Solomon Islands. American Anthropologist, 111(4), 480-491. doi.org/10.1111/ j.1548-1433.2009.01157.x

McDougall, D. (2012). Stealing foreign words, recovering local treasures: Bible translation and vernacular literacy on Ranongga (Solomon Islands). The Australian Journal of Anthropology, 23(3), 318-339.

McDougall, D. (2013). Evangelical public culture: Making stranger-citizens in Solomon Islands. In M. Tomlinson \& D. McDougall (Eds), Christian politics in Oceania (pp. 122-145). New York, NY: Berghahn Books.

McDougall, D. (2014). 'Tired for nothing'? Women, chiefs and the domestication of customary authority in Solomon Islands. In M. Jolly \& H. Choi (Eds), Divine domesticities: Christian paradoxes in Asia and the Pacific (pp. 199-224). Canberra, ACT: ANU E Press. doi.org/10.22459/DD.10.2014

McDougall, D. (2016). Engaging with strangers: Love and violence in the rural Solomon Islands. New York, NY: Berghahn Books.

McDougall. D. (2019, 20 September). Reviving the spirit of vernacular languages. ARC Centre of Excellence for the Dynamics of Language. Retrieved from www. dynamicsoflanguage.edu.au/news-and-media/latest-headlines/article/?id= reviving-the-spirit-of-vernacular-languages-in-solomon-islands

McDougall, D. \& Zobule, A. G. (forthcoming). 'All read well': Schooling on solid ground in a Solomon Islands language movement. The Contemporary Pacific, 33(2).

Merlan, F. \& Rumsey, A. (2015). Language ecology, language policy and pedagogical practice in a Papua New Guinea highland community. Language and Linguistics in Melanesia, 33(1), 82-96.

Ministry of Education and Human Resource Development. (2010). Policy statement and guidelines for the use of vernacular languages and English in education in Solomon Islands. Honiara, Solomon Islands: Solomon Islands Government.

Ministry of Education and Human Resource Development. (2013). Performance assessment report (2006-2013). Honiara, Solomon Islands: Solomon Islands Government. Retrieved from www.mehrd.gov.sb/

Ministry of Education and Human Resource Development. (2015). Performance assessment report (2010-2014). Retrieved from www.mehrd.gov.sb/ 
Ministry of Education and Human Resource Development. (2019). Performance assessment report 2018. Retrieved from www.mehrd.gov.sb/

Munro, J. (2013). The violence of inflated possibilities: Education, transformation and diminishment in Wamena, Papua. Indonesia, 95, 25-46. doi.org/10.5728/ indonesia.95.0025

Munro, J. (2017). Gender struggles of educated men in the Papuan highlands. In M. Macintyre \& C. Spark (Eds), Transformations of gender in Melanesia (pp. 45-68). Canberra, ACT: ANU Press. doi.org/10.22459/TGM.02.2017

Munro, J. (2018). Dreams made small: The education of Papuan highlanders in Indonesia. New York, NY: Berghahn Books.

Plan International. (2019). Our education, our future: Pacific girls leading change to create better access to secondary education: Solomon Islands. Retrieved from www.plan.org.au/-/media/plan/images/learn/who-we-are/blog-media-images/ 2019/200519-sols-report/our-education-our-future_policy-reportcompressed. pdf?la=en\&hash=C58B84266055B5E31D8C0088475DA3942B258032

Solomon Islands Statistics Office. (2012). 2009 Population and housing census: National report (Vol. 2). Honiara: Solomon Islands Government. Retrieved from sdd.spc.int/sb

Spark, C. (2011). Gender trouble in town: Educated women eluding male domination, gender violence and marriage in PNG. The Asia Pacific Journal of Anthropology, 12(2), 164-179.

Spark, C. (2017). 'I won't go hungry if he's not around': 'Working class' urban Melanesian women's agency in intimate relationships. In M. Macintyre \& C. Spark (Eds), Transformations of gender in Melanesia (pp. 115-140). Canberra, ACT: ANU Press. doi.org/10.22459/TGM.02.2017

Suti, E., Hoatson, L., Tafunai, A. \& Cox, J. (2020). Livelihoods, leadership, linkages and locality: The Simbo for Change project. Asia Pacific Viewpoint. doi.org/10.1111/apv.12260

Tanangada, L. O. (2013). A study of language use in secondary school classrooms in the Solomon Islands: Conceptions, practices and proficiencies (Unpublished Master's thesis). Waikato University, Hamilton, New Zealand.

Taylor, J. P. (2008). The social life of rights: 'Gender antagonism', modernity and Raet in Vanuatu. The Australian Journal of Anthropology, 19(2), 165-178. doi.org/10.1111/j.1835-9310.2008.tb00120.x

Tengan, T. P. K. (2008). Native men remade: Gender and nation in contemporary Hawai $i$. Durham, NC: Duke University Press. 
Troolin, D. (2013). Navigating contested terrain: Vernacular education in a Papua New Guinean Village. Current Issues in Language Planning, 14(2), 283-299.

United Nations Educational, Scientific and Cultural Organization. (1953). The use of vernacular languages in education. Paris, France: UNESCO.

Wardlow, H. (2006). Wayward women: Sexuality and agency in a New Guinea society. Berkeley, CA: University of California Press.

Watson-Gegeo, K. A. (1987). English in the Solomon Islands. World Englishes, 6(1), 21-32.

Watson-Gegeo, K. A. \& Gegeo, D. W. (1992a). Keeping culture out of the classroom in rural Solomon Islands Schools: A critical analysis. The Journal of Educational Foundations, 8(2), 27-55.

Watson-Gegeo, K. A. \& Gegeo, D. W. (1992b). Schooling, knowledge and power: Social transformation in the Solomon Islands. Anthropology \& Education Quarterly, 23(1), 10-29.

Whalan, J. (2011). Aid for education in post-conflict Solomon Islands. Prospects, 41(2), 237-247.

Wilkinson, R. G. \& Pickett, K. (2009). The spirit level: Why more equal societies almost always do better. London, England: Allen Lane.

Zimmer-Tamakoshi, L. (1997). The last big man: Development and men's discontents in the Papua New Guinea Highlands. Oceania, 68(2), 107-122.

Zimmer-Tamakoshi, L. (1998). Women in town: Housewives, homemakers and household managers. In L. Zimmer-Tamakoshi (Ed.), Modern Papua New Guinea (pp. 195-210). Kirksville, MO: Thomas Jefferson University Press.

Zimmer-Tamakoshi, L. (2016). Inequality and changing masculinities among the Gende in Papua New Guinea: The 'good', the 'bad' and the 'very bad'. The Asia Pacific Journal of Anthropology, 17(3-4), 250-267.

Zobule, A. G. (2016). Kulu Language Institute curriculum (Vols. 1-8). Solomon Islands: Kulu Language Institute.

Zobule, A. G. (2018, November). Studying the vernacular in the vernacular by the vernacular speakers: The case of the Kulu Language Institute in the Solomon Islands [Public lecture]. ARC Centre of Excellence in Language Dynamics, The Australian National University, Canberra, ACT. 
This text is taken from Unequal Lives: Gender, Race and Class in the Western Pacific, edited by Nicholas A. Bainton, Debra McDougall, Kalissa Alexeyeff and John Cox, published 2021 by ANU Press, The Australian National University, Canberra, Australia.

doi.org/10.22459/UE.2020.07 